\title{
Reasons Why Thai Employees Want to Join Labor Unions: Evidence in Private Companies and State Enterprises
}

\author{
Chaturong Napathorn (Corresponding author) \\ Department of Human Resource and Organization Management, Faculty of Commerce and Accountancy \\ Thammasat University, Rangsit campus, Klongluang, Pathumthani 12121, Thailand \\ Tel: 662-696-5905 E-mail: chaturon@tu.ac.th \\ Suchada Chanprateep \\ Department of Microbiology, Faculty of Science \\ Chulalongkorn University, Phayathai Road, Patumwan, Bangkok 10330, Thailand \\ Tel: 662-218-5070Ｅ-mail: suchada.cha@chula.ac.th
}

Received: May 28, 2011

doi:10.5539/ijbm.v6n12p58
Accepted: August 4, $2011 \quad$ Published: December 1, 2011

URL: http://dx.doi.org/10.5539/ijbm.v6n12p58

The research is financed by Faculty of Commerce and Accountancy, Thammasat University through Business Research Center Grant (Mini-research grant, FY 2009).

\begin{abstract}
This study provides an empirical analysis of reasons why Thai employees want to join labor unions in order to deepen our understanding of unionization-related issues in Thailand. The presidents, leaders and members of labor unions for nine private companies and two state enterprises participated in this survey. Based on 1841 valid responses from a total population of 44573 persons, our findings demonstrated that there are three main reasons why Thai employees want to join labor unions: compensation, safeguard against dismissal, and legal consultation (in descending order).
\end{abstract}

Keywords: Labor union, Thai employees, Labor relations, Labor market

\section{Introduction}

Labor unions have been viewed as organizations established to help protect the interests of employees and foster pleasant relationships between employees and employers (Webb, 1896; Pongpangan, 1979; Somprasong, 1979; Tosuwanjinda, 2002; Wilawan, 2007; Napathorn and Chanprateep, 2011 (a); Napathorn and Chanprateep, 2011 (b)). Much research has examined the reasons why employees want to join labor unions, especially in the United States and Europe (Wheeler and McClendon, 1991; Waddington and Whiston, 1997; Visser, 2002; Friedman, Abraham, and Thomas, 2006). For example, employees in the United States joined labor unions to improve work environments, career prospects, and job satisfaction (Friedman, Abraham, and Thomas, 2006). Employees in Poland joined labor unions to improve their career prospects (Zientara and Kuczynski, 2009). However, little attention has been paid to this issue in South East Asia, especially in Thailand. This lack of research attention may be because the labor relations climate in Thailand has been considered autocratic (Deyo, 1995). The labor relations system seems to be under the control of the management. Thai employees are not eager to organize labor unions because of cultural factors (Siengthai, 1993; Levine, 1997; Suthakavatin, 2005; Siengthai and Bechter, 2005). Most Thai employees view themselves to have a low rank in the organizational hierarchy; thus, they pay respect to managers whom they believe to have a higher rank within the organization. Therefore, they prefer not to create adversarial relationships with managers establishing labor unions to protect their own rights. Moreover, most managers have a negative perception of labor unions and thus do not welcome the establishment of labor unions within their workplace. Some managers also view labor unions as self-interested since some labor unions are established for personal rather than public purposes (Brown, 2004).

In this study, we conducted a study using well-designed questionnaires and in-depth interviews with labor union members from thirteen leading Thai labor unions for private companies and state enterprises. The questionnaires 
and interviews sought to determine the reasons why union members join labor unions. The research methodology and findings are discussed, and conclusions are made with respect to the reasons why Thai employees want to join labor unions.

\section{Overview of the Thai Labor Market and Labor Relations}

Regarding the structure of the Thai labor market, the agricultural sector has been the largest employment sector in Thailand for centuries and it currently has approximately 14.6 million workers (Saichua, 2010). However, since the national industrialization strategy and the economic development of Thailand focus on manufacturing for exports, a large number of workers have moved from the agricultural sector to the manufacturing sector. Not surprisingly, the share of agricultural products in the GDP has decreased continuously (Pholphirul, 2009). The government should pay attention to this movement. Although movement from one sector to another is not a new issue, the government should provide clearer direction of Thai agricultural development; otherwise, the movement will continue in the future and may affect the image of Thailand as the agricultural-based economy. Another sector that should not be overlooked is the service sector. The service sector in Thailand includes 6 million workers in wholesale and retail services, 2.6 million workers in hotel and restaurant services, and approximately 1 million workers from financial and real estate services. Thus, there are approximately 10 million workers in the service sector (Saichua, 2010). However, because of the policies regarding economic and financial liberalization as well as the free trade agreement, Thai workers, especially in the service sector, need to develop their skills and abilities in order to survive in the new work environment and to be able to compete with foreign competitors who will be able to conduct several types of businesses like their Thai counterparts. Regarding the informal sector, which is the catch basin for people who cannot find jobs in the relatively small formal sector of Thai economy, the number of laborers is likely to increase continuously. Globalization seems to be the force that leads to new types of employment, such as contract workers, part-time workers, and outsourcing workers, in Thailand, but the main problem is that these workers are not fully protected by labor laws (Pholphirul, 2009; Levine, 1997).

Regarding the labor relations system in Thailand, during the years from 1987 to 1990, the Social Insurance Act was first issued. Moreover, it is interesting to note that the Labor Relations Act, which was in force for almost 20 years, was not amended or improved during this period. The labor leaders did not address the amendment or improvement of such Act. Rather, they addressed issues regarding minimum wages, the Social Insurance Act, and laws concerning occupational health and safety. Another issue that labor leaders did not address concerned the lack of unity among the Thai labor movement. Conflicts among labor union leaders occurred several times during this period. Later, the labor union leaders focused on the election of expert lay-judges in the labor court and the election of the Chief of the Advisory Committee for Labor Development (Jandaravitoon, 2001). That is to say, the labor leaders were addressed issues related to their own personal interests instead of the public interests. The economic crisis that began in 1997 (called Tom-Yum-Kung Crisis) seriously affected the economy, labor, workers, and new graduates. Many workers and laborers were laid off because of the decrease in the demand for labor in the public and private sectors (Khinkaew, 1999). New graduates could not find jobs or spent longer searching for jobs. Some people moved back to rural provinces. Similar to the Tom-Yum-Kung Crisis, the Hamburger Crisis also affected laborers and workers in the country. Because of the mass layoffs of workers especially among factories and companies in the Thai export sector, workers and employers were likely to have conflicts. Employers closed down factories and laid off all affiliated workers in order to survive the crisis, and employees went on strike to protect their labor rights. The number of laid-off workers in Thailand has continuously increased. Labor-management relations have worsened. Labor unions are considered the last source of protection for Thai employees from being laid off or being exploited by employers.

\section{Research Methods}

\subsection{Development of the Measuring Instrument}

This study commenced with in-depth interviews of presidents, union board members, and members of thirteen leading labor unions for six well-known industries in Thailand (Table 1). Open-ended questions and semi-structured interviews were used to allow for varied responses among the interviewees. Subsequently, utilizing data from the interviewees and a literature review, questionnaires were designed to evaluate the reasons why Thai employees/workers join labor unions.

To ensure the reliability, validity, and appropriateness of the data collection instrument, two experienced labor union leaders in Thailand verified the questions, and a pilot test was conducted with 50 people who included members of academia, members of labor unions, and students who were studying labor relations at the university. Then, the researcher tested the instrument's reliability again by applying Cronbach's Alpha Method.

The final questionnaire used in this survey can be classified into 2 sections. The first section evaluated the demographic information of the respondents, namely, gender, age, duration of employment within the 
organization, duration of membership within the labor union, educational level, current position/level, income level, and marital status. The second section of the questionnaire was designed to examine why the respondents joined a labor union. The respondents were asked to rate their level of agreement for each statement starting from "Strongly Agree" to "Strongly Disagree" (5 Levels).

\subsection{Data Collection}

Presidents, union board members, and members of labor unions for private companies and state enterprises were formally invited to participate in the survey. All of the presidents and union board members allowed the researcher to visit their sites and distribute the questionnaires. Some labor unions had a large number of members, so their presidents or board members distributed the questionnaires to their members on behalf of the researcher. Out of 44573 persons in eleven leading labor unions in Thailand, a sampling size of 1490 persons was needed to achieve a confidence interval of $95 \%$ with an error of $5 \%$. Moreover, the researchers assumed that approximately $30 \%$ of the respondents would complete and return the questionnaires. Hence, the researcher distributed 3,200 questionnaires in total to obtain at least 1490 questionnaires. The actual number of questionnaires returned was $1841(\mathrm{~N}=1841)$.

\subsection{Limitation of the Research Methods}

Several limitations of this study should be considered. First, the results may only be applied to the current situation in Thailand since cultures and attitudes of people are different from one country to another. Second, the results may not represent the whole population of union members in Thailand. However, the researcher attempted to select the leading labor unions in each well-known industrial sector together with state enterprises in Thailand in order to obtain appropriate and valid data regarding Reasons Why Thai Employees Want to Join Labor Unions. Third, respondent bias may also affect the results.

\section{Findings}

\subsection{Profile of the Respondents}

A summary of the demographic profile of respondents is presented in Table 2. Males and females constituted $72.6 \%$ and $27.4 \%$ of the sample, respectively. The average age of the respondents was 41 years. Approximately $45.1 \%$ of the respondents completed a secondary education or had vocational certificates. Approximately $5 \%$ of the respondents completed a primary education, and approximately $17.4 \%$ received their high school diploma. Additionally, approximately $32.5 \%$ had an undergraduate or postgraduate degree. In terms of marital status, $75.5 \%$ of the respondents were married, $19.6 \%$ were single, and the rest were divorced. With respect to the duration of employment within the organization, the average duration was 17.31 years. For the duration of membership within the labor union, the average duration was 14.59 years. With regard to the personal monthly income, $42.6 \%$ of the respondents earned salaries in the range of 10000-29999 Baht. Lastly, $99.5 \%$ of the respondents were full-time employees, and the rest were part-time employees.

\section{Data Analysis and Discussion}

\subsection{Data Analysis}

Among 15 statements regarding the reasons why Thai employees/workers join labor unions, the researcher extracted only five statements that were rated highest; these statements are presented in Table 3 . The statement, "I joined a labor union because labor unions will represent me in annually negotiating with employers regarding salary increases and bonuses" scored the highest with a mean score of 4.56. The statement, "I joined a labor union because the labor union will protect me from being dismissed from the company without cause" scored the second highest with a mean score of 4.47. The statement, "I joined a labor union because the labor union acts as the legal consultant (especially in labor law) for me and will help me in negotiating with employers" scored the third highest with a mean score of 4.35. The statement "I joined a labor union because the labor union will help protect member benefits and because the labor union understands the needs of its members" scored the second lowest with a mean score of 4.14. While the statement "I joined a labor union because the labor union will help protect the long-term benefits of its members until such members retire from the company" scored the lowest with a mean score of 4.06 .

\subsection{Discussion}

From the findings above, 3 main categories emerge regarding the reasons why Thai employees join labor unions.

\subsubsection{Compensation}

Since the statement "I joined a labor union because the labor union will represent me in annually negotiating with employers regarding salary increases and bonuses" scored the highest with a mean score of 4.56, the statement "I joined a labor union because the labor union will help protect member benefits and because the labor union understands the needs of its members" scored the second lowest with a mean score of 4.14, and the 
statement "I joined a labor union because the labor union will help protect the long-term benefits of its members until such members retire from the company" scored the lowest with a mean score of 4.06, the researcher concludes that the main reasons why Thai employees/workers join labor unions relate to compensation. Most Thai employees/workers consider wage or salary, including bonuses, to be one of the most important factors in improving their daily lives and well-being; they must receive a sufficient wage or salary to support themselves and their families. Therefore, they join labor unions because they believe that labor unions will represent them in negotiating with employers regarding wage or salary increases, as well as annual bonuses. After the negotiations, if an employer offers a substantial wage or salary increase and a substantial annual bonus, the labor union is perceived as strong and powerful, and current labor union members will trust and support the labor union. In addition, new employees/workers will join such labor unions. Thus, the number of labor union members will increase, and strength and power of the labor unions will increase (Napathorn and Chanprateep, 2011, February; Napathorn and Chanprateep, 2011, June). On the other hand, if a labor union fails to negotiate a wage or salary increase and annual bonus, current labor union members may lose faith and confidence in the labor union as the organization responsible for protecting their own interests within the workplace. New employees/workers will not join the labor union since they believe that joining the union is useless, especially consider the monthly labor union fees. Such a labor union will become weaker and less powerful (Napathorn and Chanprateep, 2011, february; Napathorn and Chanprateep, 2011, June). Not surprisingly, compensation is the most important reason why Thai employees/workers join labor unions.

\subsubsection{Safeguard against Dismissal}

Since the statement "I joined a labor union because the labor union will protect me from being dismissed from the company without cause" scored the second highest with a mean score of 4.47, the researcher summarizes that the second most important reason why Thai employees/workers join labor unions is that labor unions can safeguard employees/workers against dismissal. During the economic crisis, many companies and factories, especially in the export sector, laid off and dismissed a large number of employees/workers without any appropriate reason in order to reduce labor costs and to survive the crisis. Some factories closed down during the economic crisis without notifying their employees/workers in advance. Those employees/workers went on strike or went to claim their rights and pledged for support from the Ministry of Labor. Under such circumstances, conflicts between workers and employers occur. The collective bargaining system at the national, industry, and (especially) workplace levels should allow for more communication and cooperation among the main three parties - employers, employees or labor unions, and the government - to reduce the tension and conflicts between employers and employees and to foster positive labor-management relations. The labor unions, as entities established to protect the rights of employees or workers, should act as the safeguard for employees in case that the employers exploit employees or dismiss employees from the company without appropriate causes.

Accordingly, most of Thai employees/workers, especially blue-collar workers, expect labor unions to help protect them from being dismissed from their companies. The labor unions may, at the very least, provide employees/workers with advice or suggestions in protecting their rights of their members and may help employees claim money damages from a labor court or any relevant mechanisms should any of those rights be violated. However, labor union leaders must pay attention to the general interests of employees/workers instead of their individual interests (Jandaravitoon, 2001) in order to support the labor unions as powerful organizations responsible for effectively protecting the rights of employees/workers. In addition to labor union leaders, labor union committees are also crucial (Thanachaisetthavut, 1996). In our in-depth interviews with labor union members, we found that if the labor union leaders and committees pay attention to their individual interests instead of to general interests, labor union members may lose faith and confidence in the labor union's ability to protect them within the workplace.

\subsubsection{Legal Consultant}

Since the statement "I joined a labor union because the labor union acts as the legal consultant (especially in labor law) for me and will help me in negotiating with employers" scored the third highest with a mean score of 4.35, the researcher concludes that the third most important reason why Thai employees/workers join labor unions is that Thai employees/workers require advice from the labor union as a legal consultant, especially with regard to labor law matters. In addition, Thai employees/workers believe that being a member of a labor union will help them in negotiating with employers in matters concerning social insurance, overtime pay, allowances, bonuses, wage or salary increases, and so forth.

However, Hofstede (1984) and Suthakavatin (2005) found that most Thai people are normally not energetic and enthusiastic about participating in activities that do not pertain to their own struggles. Most Thai employees/workers think about labor unions only when they personally face labor issues and believe that labor unions can act as their legal consultant to help them overcome these issues. However, if they are not involved in a legal controversy, they may never consider the importance of a labor union. From our in-depth interviews with 
labor union members in this study, labor union members told us the reason why they seldom participate in labor union activities is because most members of labor unions are poor. They work from 8:00 am to 5:00 pm and then work overtime for 2 to 3 hours in order to earn a living and support their families. After working for 10 or 11 hours a day, 6 days a week, most workers feel exhausted and have no energy to participate in labor union activities. Thus, most of them prefer to be followers instead of leaders in establishing their rights and benefits with their employers. This issue might ultimately weaken the power and influence of labor unions as organizations responsible for protecting the rights and benefits of Thai employees/workers as a whole.

\section{Conclusion}

This study provides a better understanding regarding the reasons why Thai employees/workers join labor unions. The sample in this study was drawn from leaders and members in several leading labor unions for private companies and state enterprises in Thailand. After conducting a literature review, interviewing leaders and members of thirteen labor unions in Thailand, distributing questionnaires, and conducting statistical tests, the researcher concluded that there are three main reasons why Thai employees/workers want to join labor unions: compensation, safeguard against dismissal, and legal consultation. We believe that this study offers some important insights into Thai employees' intent to join labor unions and that it will help to deepen the understanding of unionization-related issues in Thailand. However, the results may not be generalizable to the whole population of leaders and members of labor unions in Thailand. Nevertheless, the researcher tried to balance the limitations by collecting data from thirteen leading labor unions in six well-known sectors of Thailand in order to obtain the most appropriate and valid dataset. In addition, the researcher has not made an attempt to discuss the measure of individual effects on the statistical models. That is to say, the question of whether the characteristics of the respondents affected the reasons why Thai employees/workers join labor unions remains unanswered. Thus, further research into this issue should be conducted.

\section{Acknowledgments}

This work was supported in part by Faculty of Commerce and Accountancy, Thammasat University through Business Research Center Grant (Mini-research grant, FY 2009).

\section{References}

Brown, A. (2004). Labour, politics and the State in industrializing Thailand. London: Routledge Curzon.

Deyo, F. C. (1995). Human Resource Strategies and Industrial Restructuring in Thailand. S. Frenkel, \& J. Harrod (Eds.), Industrialization and Labor Relations: Contemporary Research in Seven Countries (pp.23-26). Ithaca, NY: ILR Press.

Friedman, B. A., Abraham, S.E., \& Thomas R.K. (2006). Factors Related to Employees' Desire to Join and Leave Unions. Industrial Relations, 45, (1), 102-110.

Hofstede, G. (1984). Culture's Consequences: International Differences in Work-Related Values. (pp.111-191). Abridged edition. Beverly Hills London: Sage Publications.

Jandaravitoon, N. (2001). Thai labour: 35 years along Thailand's economic growth. Bangkok: Chulalongkorn University Printing House.

Khinkaew, B. (1999). Country Papers: Thailand', In Asian Productivity Organization, Labour-management Cooperation: Collective Bargaining as a Means to Promote Cooperation. (pp.219-223). Tokyo: Nihon Printing.

Levine, M. J. (1997). Worker rights and labor standards in Asia's four new tigers: A Comparative Perspective'. (pp. 255-268). US: Springer.

Napathorn, C., \& Chanprateep, S. (2011, February). What Types of Factors Can Influence the Strength of Labor Unions in Companies and State Enterprises in Thailand? International Journal of Business and Management, 6(2), 112-124.

Napathorn, C., \& Chanprateep, S. (2011, June). Recent Labor Relations and Collective Bargaining Issues in Thailand [Electronic Version]. Interdisciplinary Journal of Research in Business, 1(6), 66-81.

Pholphirul, P. (2009). Thai workers under wave of globalization. NIDA Development Journal, 49(3), 39-74.

Pongpangan, A. (1979). Labor (Translated from Thai Title). Bangkok: Borpit Printing House.

Saichua, S. (2010). Production and employment. [Online] Available: http://www.nidambe11.net/ekonomiz/2010 q2/2010april22p4.htm (February 20, 2011).

Siengthai, S. (1993, December). Tripartism and industrialization of Thailand. A research paper prepared for the ILO, ESCAP: Thailand.

Siengthai, S., \& Bechter, C. (2005). Human Resource Management in Thailand: A Strategic Transition for Firm 
competitiveness, Research and Practice in Human Resource Management, 13(1): 18-29.

Somprasong, J. (1978). Labor relations: Theory and practice (translated from Thai title). Bangkok: Borpit Printing House.

Suthakavatin, T. (2005). Comparative labour relations (translated from Thai title). Bangkok: TPN Press.

Thanachaisettavut, B. (1994). Rights of Thai labour in an era of globalisation. Bangkok: Arom Pong Pa-Ngan Foundation \& Asian-American Free Labour Institute (AAFLI).

Tosuwanjinda, V. (2002). Labor relations: The key to the cooperation between employers and employees (translated from Thai title). ( $5^{\text {th }}$ ed.) Bangkok: Nititham Press.

Visser, J. (2002). Why Fewer Workers Join Unions in Europe. British Journal of Industrial Relations, 40(3), 403-30. http://dx.doi.org/10.1111/1467-8543.00241

Waddington, J., \& Whitston, C. (1997). Why Do People Join Unions in a Period of Membership Decline? British Journal of Industrial Relations, 35(4), 515-546. http://dx.doi.org/10.1111/1467-8543.00067

Webb, S., \& Webb, B. (1896). History of Trade Unionism. London: Longman.

Wheeler, H.N., \& McClendon, J. A. (1991). The Individual Decision to Unionize. In G. Strauss, D.G. Gallagher, \& J. Fiorito (Eds.), The State of the Unions (pp.47-83). Madison, WI: Industrial Relations Research Association.

Wilawan, K. (2007). Labor relation (translated from Thai title). (10 $10^{\text {th }}$ ed.), Bangkok: Winyuchon Press.

Zientara, P., \& Kuczynski, G. (2009). Employees' Desire to Join or Leave a Union: Evidence from Poland. Industrial Relations, 48(1), 185-191. http://dx.doi.org/10.1111/j.1468-232X.2008.00550.x

Table 1. Thirteen Thai Leading Labor Unions in Six Well-Known Industries Interviewed by the Author

\begin{tabular}{|c|c|c|c|c|}
\hline Industry & Name of Labor Union (s) & $\begin{array}{c}\text { Total } \\
\text { population }\end{array}$ & $\begin{array}{c}\text { Sampling } \\
\text { size }\end{array}$ & $\begin{array}{c}\text { Number of } \\
\text { questionnaires } \\
\text { returned }\end{array}$ \\
\hline \multirow{3}{*}{ Automobile Industry } & Toyota Thailand Workers' Union & 4,600 & 154 & 221 \\
\hline & Honda Workers' Union of Thailand & 2,515 & 84 & 106 \\
\hline & $\begin{array}{l}\text { Isuzu Engine and Parts Worker's } \\
\text { Union }\end{array}$ & 747 & 25 & 39 \\
\hline \multirow{2}{*}{$\begin{array}{l}\text { Petroleum and } \\
\text { Chemical Industry }\end{array}$} & Thai Bridgestone Labor Union & 270 & 9 & 20 \\
\hline & Thai Carbon Black Labor Union & 2000 & 67 & 69 \\
\hline \multirow{2}{*}{$\begin{array}{l}\text { Food and Beverages } \\
\text { Industry }\end{array}$} & Siam Foods Labor Union & 630 & 21 & 46 \\
\hline & Foremost Thailand Workers Union & 368 & 13 & 33 \\
\hline \multirow{2}{*}{$\begin{array}{l}\text { Garment and Textile } \\
\text { Industry }\end{array}$} & Thai Rayon Labor Union & 816 & 28 & 67 \\
\hline & Teijin Polyesters Workers Union & 627 & 21 & 35 \\
\hline \multirow{2}{*}{$\begin{array}{l}\text { Finance and Banking } \\
\text { Industry }\end{array}$} & Bangkok Bank Workers Union & \multirow{2}{*}{\multicolumn{3}{|c|}{$\begin{array}{l}\text { In-depth interview with the founder and } \\
\text { cofounder }\end{array}$}} \\
\hline & Thai Farmers Bank Labour Union & & & \\
\hline \multirow[t]{2}{*}{ State Enterprises } & $\begin{array}{l}\text { The Labor Union of Electricity } \\
\text { Generating Authority of Thailand }\end{array}$ & 16000 & 534 & 608 \\
\hline & TOT Workers' Union & 16000 & 534 & 597 \\
\hline Total Number & 11 Unions & 44573 & 1490 & 1841 \\
\hline
\end{tabular}


Table 2. Demographic Profile of Respondents $(\mathrm{N}=1841)$

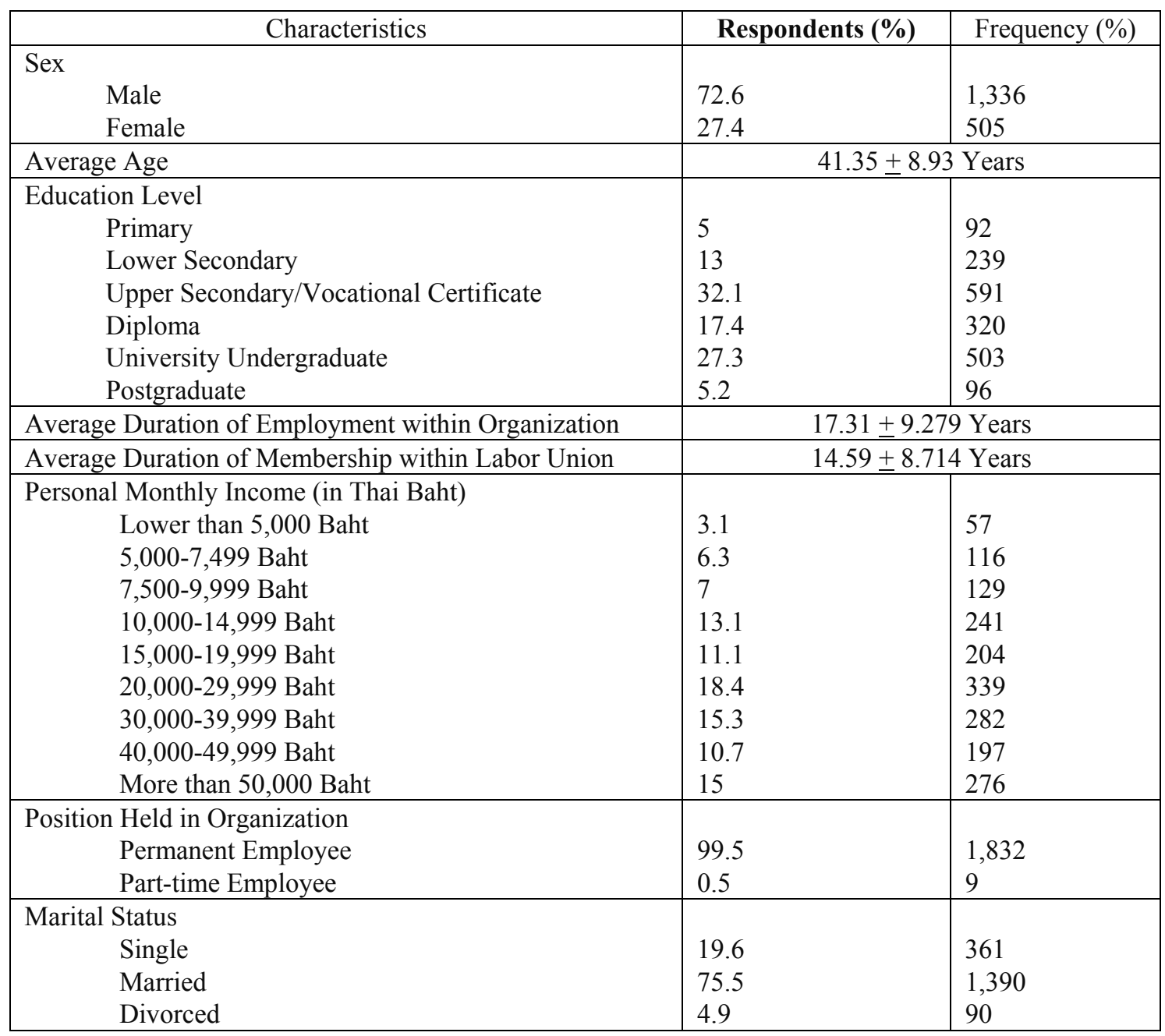

Table 3. Mean Ratings of Statements Regarding Reasons Why Thai Employees/ Workers Join Labor Unions

\begin{tabular}{|l|c|c|}
\hline \multicolumn{1}{|c|}{ Statement } & Mean $^{\text {a }}$ & S.D. \\
\hline $\begin{array}{l}\text { "I joined labor union because labor unions will act as my representative in } \\
\text { annually negotiating with employers regarding the salary increase and bonus" }\end{array}$ & $4.56^{\mathrm{b}}$ & 0.894 \\
\hline $\begin{array}{l}\text { "I joined labor union because labor union will protect me from being dismissed } \\
\text { from the company without any appropriate reason" }\end{array}$ & 4.47 & 0.896 \\
$\begin{array}{l}\text { "I joined labor union because labor union acts as the legal consultant } \\
\text { (especially in labor law) for me and will help foster my power and influence } \\
\text { when negotiating with employers in any case" }\end{array}$ & 4.35 & 1.012 \\
\hline $\begin{array}{l}\text { "I joined labor union because labor union will help protect every kind of } \\
\text { member's benefits and because labor union understands the needs of its } \\
\text { members" }\end{array}$ & 4.14 & 0.915 \\
\hline $\begin{array}{l}\text { "I joined labor union because labor union will help protect long-term benefits } \\
\text { of its members until such members retire from the company" }\end{array}$ & $4.06^{\mathrm{c}}$ & 1.071 \\
\hline
\end{tabular}

a Five-point Likert scale was used for rating the issues ranging from $1=$ "strongly disagree" to $5=$ "strongly agree".

${ }^{b}$ The highest mean among five issues.

$c$ The lowest mean among five issues. 